\title{
DRAMATIC LITERATURE, DIGITISATION AND \\ CULTURAL MEDIATISATION: A POSTMODERNIST PERSPECTIVE
}

\author{
Clement Olujide Ajidahun* \\ http://dx.doi.org/10.4314/og.v13i 1.10
}

\begin{abstract}
Literature, unarguably, mirrors and reflects the essence of the society in all its socio-cultural and ethno-political ramifications. It captures the self-esteem of the society; it also symbolizes the psyche of the society. Literature, therefore, becomes a tool for measuring, archiving and transmitting the societal ethos and values. In some climes, literature is seen as the highest expression of the creative verve. It becomes very compelling for it to respond to and capture the societal changes that occur periodically. This paper uses the postmodernism theory that validates the modernist literature and the cultivation theory that examines the psychological impact of the media on the audience as the theoretical framework to examine the paradigm shift from the traditional mode of literary communication to the new changes imposed on the literary tradition with the advent of the new communication channels like the internet and the World Wide Web and other new communicating devices. The paper discusses the classical literary genres and the modifications created by the digital technologies. It also discusses the impact of digital technology on the African literature from the literary, legal, pedagogical, socio-cultural and moral perspectives. The future of creativity and the possible emergence of new canons for critiquing the new media are considered.
\end{abstract}

Keywords: New Media, Digitisation, Dramatic Literature, Postmodernism Criticism.

\section{Introduction}

The advent of information communication technologies has been globally acknowledged as a computer revolution. Indisputably, therefore, the $21^{\text {st }}$ century is the digital age that is increasingly witnessing a tremendous deployment and utilization of computer technologies for social, academic, economic cultural and political 
engagements. Business and administrative transactions that were performed manually are being executed digitally with varieties of user-friendly, complex, foreign and domesticated software packages to reflect the realities of the modern age. The teaching and learning ecology is steadily bowing to a wired and digitized environment. The interface between the teacher and the learner is now purely electronic and without boundaries. The traditional library system is being deconstructed. Emphasis is no longer on the physical space but on the virtual space. Library services such as cataloguing, acquisition and bibliographic transactions are performed online. New vocabularies are emerging and they are being integrated into the lexicon of English grammar to justify the dynamism of languages.

Besides, the mode of communication and interactions has also been globalised. Writing on the concept of globalization as it affects communication, Anthony Giddens posits that "Globalization is definable by an intensification of global social interrelations by which distant localities are connected to one another in such a manner that events taking place at one locality affect those that happen many kilometers away, and vice versa" (qtd. in Nederveen Pieterse 92). The daily interactions on the social media like Facebook, YouTube, Twitter, LinkedIn, Instagram, Whatsapp, Hyper, Bebo and Ello, which are prevalent among the youths, attest to the global social interactions without walls. These social interactions empowered by interactive multimedia high technologies are aided by the avalanche of mobile devices like smartphones, cell phones, palmtops, and others like laptops, table top computers and so on. The market is inundated and flooded with all varieties of these handheld devices and communication gadgets. This paper is essentially concerned with the impact of globalization and digitization on dramatic literature from the postmodernist perspective.

\section{Theoretical Framework}

The theoretical framework of this paper is based on the postmodernist theory and the cultivation theory. Postmodernism is generally conceived as a protest and reaction to classicism and modernism. According to Alexander, it is often used interchangeably with Post-Marxism, Post-Structuralism and Post- Colonialism 
because it carries a toga of development and advancement. The postmodernist critics view the literature of modernist writers like Eliot, James Joyce and Lawrence as over ambitious, unrealistic and therefore inadequate just as the modernist writers like D.H. Lawrence, T.S. Eliot and others did of Victorian writers (Alexander 399).

Modernism as a movement was strengthened by its belief in the inviolability and sovereignty of science as the solution to the enigmatic and imponderable issues of life. Science was then believed to possess the ability to demystify the mysteries of life. This belief, consequently, led to the advancement in science and technology. With the emergence of Charles Darwin's controversial theory of evolution, the traditional belief system was seriously tackled. The essence of postmodernism is, therefore, to deconstruct modernism (Danesi 173).

Postmodernism, as a modern literary theory, is believed by critics to be broader in scope than Marxism and Post-Structuralism. Some of the postmodernist critics and theorists are Jean Baudriallard, Jean-Francois Lyotard, Georges Bataille, Terry Eagleton and others. The postmodernism movement defines the evolution of a society that is characterised by "global extension of capitalist markets, mass migration of labour, the predominating role of mass media and images, unprecedented economic and cultural interaction between various parts of the world, media images and the various technologies and instructional codes" (Habib 246-247).

The paper also considers the cultivation theory in social psychology as a veritable basis for this discourse. The Cultivation theory that was developed by George Gerbner examines "the mass media as a socializing agent and investigates whether television viewers come to believe the television version of reality the more they watch it" (Gerbner 41). While social psychologists believe in the integration of the new media into daily interactions and activities, they are also disturbed about the media effects and influences on the society. Cultivation theory is concerned about the accumulative effects of the "symbolic environment engendered by the new media especially in the creation of fear and violence as well as its debilitating effects on the traditional and social lives in the community. Social scientists and psychologists have also been concerned with the impact of the new media in alleviating or 
aggravating the societal problems (Hodgetts et al, 339-347). This is the hallmark of cultivation theory. This paper will look at the relevance of the theory to cultural mediatisation and its effects on literature.

\section{Dramatic Literature and Digitisation}

The impact of globalization on the literary tradition has been viewed by postcolonial critics as a form of imperialism just as economic imperialism is seen as a product of globalization. Toyo defines economic imperialism as "the assertion of the economic hegemony of one nation over another from which the hegemon profits" (Toyo 9). It follows; therefore, that literary imperialism is one of the manifestations of globalization, although this view is debatable. This is because not all global interactions are imperialistic. It is still possible to interact with other countries without losing our values. Postcolonial critics examine and analyse the economic, political and cultural impacts of imperialism on the society from the perspectives of the colonised and the colonists.

Again, one of the ideologies of the theory is the call for a return to the indigenous literary traditions in order to wrest the cultural heritage of the Blacks from the grip of imperial subjugation. It is in connection with this ideology that Ngugi, in a vociferous and rancorous manner, called for the absolute rejection of the English language as the language of African literature because it is the language of the imperialists. He, therefore, campaigned for the adoption of the indigenous languages for the expression of creative thoughts among the Blacks.

Although one does not agree totally with Ngugi's position on the rejection of the English language, Ngugi is right when he said that colonialism is responsible for the deliberate destruction of the people's culture, history, traditions, education, art and literature at the expense of the development of the language of the imperialists. Ngugi believes that the subjugation of a people's language by the languages of the imperialists is synonymous with the subjugation of the mental and psychological world of the colonised people (Ngugi 16).

Consequently, from the perspective of postcolonial theory, cultural mediatisation or digital humanities is viewed as an extension of imperialism. It alienates man from the reality and dehumanises 
man by creating an unending interface between man and an automaton. For postcolonial apologists, this creates room for boredom because the media make us to see the world as the camera sees it and not the way we want to see it. Referring to the deployment of a postmodern strategy in Godfrey Reggio's 1983 Koyaanisqatsi- a movie without locution, Danesi posits that "we see the world as the TV camera sees it. And it is turgid, gloomy world indeed with no identifiable purpose or meaning. People move around like mindless robots. To bring out the insanity of a world characterized by countless cars, decaying buildings, and crowds bustling aimlessly about" (Danesi 173). Similarly, it has been observed that "television is a "daydream machine that brings an endless number of collective daydreams and fantasies to us. This leads to a "blurring of the distinction between fact and fiction, the real world and fantasy, on the screen" (Esslin 1).

Even though cultural mediatisation is viewed from the Eurocentric perspective as multiculturalism whereby the culture and literature of various communities are promoted to enhance mutual communication and collective understanding in a globalized environment (Alexander 406), Afrocentrists are of the view that the new media culture is a calculated attempt to erode the traditional culture of the society. They are usually critical of postmodernism because of its root in Europe. That is why Afrocentricity seems to be ubiquitous by being involved in all forms of intellectual engagements including the new media to promote Blackism as an ideology. "Afrocentricity is biased against the West and blindly devoted to even the most negative aspects of African cultures" (MolefiKete Part II).

It is in the context of Eurocentrism that the existence of African literature is being denied by the West. To the West, the literature of other societies was long considered as "a logical component of anthropological and sociological studies" (Schipper 82). This lack of recognition of other literature of other cultures is viewed as a cultural and literary imperialism. Therefore, the current cultural mediatisation, which is a manifestation of globalisation, is viewed by critics as an attempt to globalise literature. The emphasis will then be on world literature. This is without prejudice to the limitless and unquantifiable number of digital resources that will be available to researchers and students of African literature in friendly 
formats and with easy accessibility in most cases with or without any financial cost.

One of the concerns that African scholars have is how African literature will function within the body of world literature. Another concern is that it will be unfair, Eurocentric and unacceptable by using the Western canons in evaluating African literature. Research shows that some students of literature in Europe when working on comparative literature said it unambiguously that there is nothing good about African literature. Even when the Western critics give recognition to the literature of other societies, their evaluations are usually from the Eurocentric perspective (Okpewho 26). At a Conference of African Writers which was held at Makerere University, Kampala in 1963, the African writers repudiated the West, in strong terms for considering themselves as specialists in Negro literature, by setting standards or the canons on what this literature should be, and consider as not African any work by an African that does not follow their creed and philosophy (African Writers 42).

Some of the implications of computers on literary texts are electronic scholarly editing, textual analysis, robotic poetics, film analysis, quantitative analysis of text, computational analysis of literary texts, text encoding, modeling and others. Besides, it is doubtful that the computer programs for textual computations and coding, the use of automated parsing and artificial intelligence will be capable of coping with the peculiar intricacies of literary studies. In the light of digitisation and mediatisation, all these will be packaged and analysed from the Western point of view without taking cognisance of the cultural peculiarities, linguistic diversities and the nuances of different societies. For instance, the existence of Nigerian English as a veritable variety of the English language is no longer a myth. From the point of view of linguistics, this variety is being referred to as a dialect of the English language (Adetugbo 137). It is being used in the literary circles to reflect the local flavour and to create an enduring identity.

The reality, as shown by research, is that this Nigerian variety of English language is prevalent among the elites and educated in Nigeria. This is a common trend among the second users of the English language. Efforts are being made to ensure that it is codified, standardised and packaged for national and international 
intelligibility. This, therefore, explains why the domestication or indigenisation of the English language is a common feature in the African literary works. Some examples are provided below to reflect the Nigerian cultural milieu:

1. IyaAgba: What I want to tell you? I thought I told you a lot before, and if you didn't have cotton wool in your ears, you would have heard my words. Niyi Osundare'sThe Man who Walked Away. Pp. 15 and 16.

2. IyaAgba: A thousand leaves in your mouth if you don't let me speak my mind! Niyi Osundare'sThe Wedding Car. P. 46.

3. Chief Chamberlain: About four weeks ago, I came back from work to find fifty bags of rice stacked up near my garage. Real long-grain American rice, not the petepetething they call in this country. NiyiOsundare'sThe Wedding Car. P. 46.

4. Baale: Speak Oluode!

Remember, I sent you myself

To join the Nightwatchmen!

I asked you to be our eyes

And our ears there! Femi Osofisan's Aringindin and the Nightwatchmen. P. 53.

5. Baba Ibeji: I'm not man enough, but $I$ put twins, two male twins too, inside your belly! Or you thought it was your mother's akara at the market that produced them? Femi Osofisan's Twingle-Twangle: A Twynning Tayle. P. 2.

It is very unlikely that the Western canons will accommodate all these domestication attempts and regard them as standard and inevitable linguistic and sociological manifestations of language dynamism and not as vernaculars, primitive, unintelligible and indecipherable. It is in this context that we think African literature, in the face of globalisation and cultural mediatisation may experience some cultural upheavals and literary emasculation in the name of technological advancement instead of cultural rejuvenation and literary renaissance. 
Besides, the structure of the theatre is quite different from that of the dramatic work. This should be considered in the mediatisation of theatrical works. In critiquing a stage play, the following are taken into consideration: Performers, Audience, Theatre Director, Space and Design. Also, the following are considered in evaluating a dramatic text: Plot, Action, Conflict, Climax, Characterisation, Setting and Unities.

\section{Theatrical Adaptation}

One of the immediate realities of the digital age is the adaptation of print literary works to films and movies. Research shows that literary adaptation has been an old phenomenon. For instance, Georges Melies pioneered Cinderella in 1899 and converted it into a film. In British drama, the following plays have been adapted to films, Death of a Salesman by Arthur Miller, A Doll's House by Ibsen Henrik, and Who's Afraid of Virginia Woolf by Edward Albee. Born Yesterday by Garson Kanin and Another Country by Julian Mitchell are also examples of adapted literary works. Quite many of the Shakespearian plays have also been adapted to films. With the upsurge of information technologies, many more dramatic works will undergo television and radio adaptations. It should be noted, therefore, that the property right of a literary work must be obtained legally before it can adapted or else, it will be tantamount to plagiarism.

Consequently, the media has thus become the newest genre of literature in addition to the traditional three literary genres of Drama, Fiction and Poetry which are all in print form. The digitisation of literary works, especially the dramatic works, poses some concern to dramatists and theatre practitioners. The utilisation of analogue technology by dramatists is being overtaken by the deployment of digital technologies which is seen by postmodernists as a radical cultural transformation. The theatre is thus technologydriven. Artists are compelled to deploy "telematic performance spaces, computerized scenography and lighting design, computerized choreography and performer, controlled stage environments, holographic actors/dancers etc." Without any doubt, this cultural mediatisation will enhance controlled and personalized media setting. (Delahunta). 
The essence of drama from the classical age is that it is to be staged by some performers and watched by an audience. This is where it is different from Fiction and Poetry that are to be read. In the theatre, the audiences experience sensory stimulation (light and sound). They can also evaluate the human values and the potential creative and intellectual values inherent in the live performance (Trumbuli 1). With the digitisation renaissance, the stage drama has now metamorphosed to movie. We, therefore, contend that this technological and cultural transformation will lead to psychological distancing and alienation of the audience from the performers who have thus been reduced to artificial and unnatural motion characters, while the dramatic setting is computerised and customised.

Similarly, the digitisation of literary materials is done arbitrarily and indiscriminately. While the digitisation of critical literary texts is a good development as it enhances scholarship and stimulates vibrant intellectual engagements, the digitisation of the primary literary sources is worrisome. Classical materials like Sophocles' Oedipus Rex and Antigone, Euripides' The Bacchae, Shakespearian plays and African plays and novels are expected to be in possession of learners and studied regularly. Students are expected to literarily chew the texts and give time for gestation until the students are virtually consumed with the texts. Such a learning attitude will take the learners to the world of the author, and they can begin to visualise and project into the mind of the author and decipher, with psychological and intuitive lens, the thoughts and the creative intents of the author. All these are not possible when such primary sources are digitised, and it is a serious development.

The stage drama tends to produce the desired cathartic effects on the audience than the adapted play into a movie. King Oedipus and Macbeth on stage appear more real than the King Oedipus and the Macbeth in films although the computer effects on such films will remove the likely crudities and stereotypes that are often seen in stage plays. Both the theatre and film dramatise scenes and stories using performers who act and represent reality. The difference is basically in the relationship of the performer to the audience. In films, the performers have no direct link with the audience but with the cameras. In a stage drama, the audience is very close to the performers. So, they must act to satisfy the theatrical curiosity of the audience. While stage acting makes voice projection 
impelling, in film acting, vocal flexibility is not a requirement. We acknowledge the fact that the stage play is more challenging and tasking as errors and inaccuracies will be intolerable and inexcusable.

Another concern is that modern drama is presentational in nature. It is an illusion of reality. The playwrights of this age dramatise rather than narrate. The act of narration was a feature of older drama, the strength of which lay in speech rather than in action, this is a signal shift from the Aristotelian concept of drama as an imitation of actions. In Greek, Roman and to some extent Elizabethan drama, for instance, murder was usually reported rather than enacted on stage, while in modern drama, murder is performed on stage. Hence, while representational drama merely reports events, the presentational mode shows the actual events and actions on stage.

Modern drama, therefore, goes beyond entertaining the audience. It aims at educating and stirring up the audience into taking some positive steps like protests and demonstrations. The audience is no longer seen as mere spectators but as active and dynamic participants in the drama. That is why modern drama is more rancorous, combative and confrontational to enhance its Marxist ideology. The ability of the modern dramatic media to engage the spectators actively and stir them up to protest against the socio injustice in the society is in doubt. This is because the actors in the media are distanced from the spectators. The actors are, therefore, seen as strangers that cannot be reached or touched unlike the stage drama.

The concern of the Cultivation theorists about cultural mediatisation and television adaptation is the overall effect of the unrestricted, unregulated and uncontrollable exposure of the teeming youths to the media. The theorists believe that this is responsible for the upsurge in the crime rate in the society. Under the guise of surfing the net for research purposes, contemporary youths are engaged in media crimes such as advanced fraud, yahoo yahoo. They are also exposed indiscriminately to pornographic sites and indecently provocative blogs advertently or unwittingly. It has been observed that "there is a sexual element to our television viewing, especially because television is a close-up medium, and thus, the most intimate of our media" (Esslin 1). These unnecessary 
Ajidahun: Dramatic literature, digitization and cultural...

distractions engendered by the new media are of interest to cultivation theorists because of their social and psychological consequences on the society.

\section{Conclusion}

The functional role of literature in the society cannot be easily overemphasised. The paper has captured the critical views and perceptions of modernist and postmodernist writers on the digital age. Some of the advantages of the digitisation of dramatic literature as captured by the paper include accessibility to limitless information resources from diverse sources that can enhance research, teaching and learning, promotion of scholarship and academic excellence, improvement of the learning ecology, evolution of the media as a new genre, socialisation and internalization of education. The paper has also expressed serious concerns on the challenges of digitisation which include cultural and literary imperialism, digitisation of primary sources, plagiarism before a dramatic text is released to the public, the status of African literature within the body of world literature, emergence of critical canons for critiquing African texts without having Eurocentric colourations, the tasks of theatrical adaptation and the moral issues attached to addiction to the media. The decolonisation of the English language is, therefore, inevitable for the digitisation of African literature in order for it to reflect its local aesthetics.

*Clement Olujide Ajidahun, Department of English Studies, Adekunle Ajasin University, Akungba Akoko, Nigeria. jideajidahun@gmail.com, jideajidahun@yahoo.co.uk 


\section{References}

Adetugbo, Abiodun. "Appropriateness and Nigerian English".Varieties and Functions of English in Nigerian: Selections from the Proceedings of the Ninth Annual Conference of the Nigerian Studies Association. Ed. EboUbahakwe. Ibadan: African UP, 1979. 137-166.

Alexander, Michael. A History of English Literature.New York: Palgrave Macmillan. Print.

Danesi, Marcel. Messages, Signs, and Meanings: A Basic Textbook in Semiotics and Communication Theory. Toronto: Canadian Scholar's Press Inc. Print.

Delahunta, Scott. "Speculative Paper: Theatre/Dance and New Media and Information Technologies." Paper Presented to the Working Groups on Dance and Drama, Research Group on Reorganisation of Professional Arts Education, Amsterdam, April 1998.

Esslin, Martin. Drama as Communication (or Drama versus Narrative): The Age of Television. Chicago: DePaul University, 1982.

Fonlon, Bernard. "African Writers Meet in Uganda". Abbia 1 (1963): 39-53.

Gerbner, G., and Gross, L. "The Scary World of TV's Heavy Viewer."Psychology Today.10 (4), 41-89.

Habib, M.A.R. Literary Criticism from Plato to the Present: An Introduction. WestSussex: Wiley-Blackwell. 2005. Print.

Hodgetts, Darrin et al. Social Psychology and Everyday Life. Houndmills: Palgrave Macmillan, 2010. Print.

Kete, Molefi. The Problem with Afrocentricity: A Book Review. An Afrocentric Manifesto. Cambridge: Polity Press, 2007. Print.

NederveenPieterse, Jan. "Der Melange-Effekt. Globalisierungim Plural."Perspektiven der Weltgesellschaft.Ed. Ulrich Beck. Frankfurt: Suhrkamp, 1998. 87-124. Print.

NgugiwaThiong'o.Decolonising the Mind: The Politics of Language in African Literature. Harare: Zimbabwe Publishing House, Ltd, 1981.Print.

Okpewho, Isidore. "Comparatism and Separatism in African Literature", World Literature Today.55.1. (1981): 25-32.

Osofisan, Femi. Aringindin and the Nightwatchmen. Ibadan: Heinemann, 1992. Print. 
Ajidahun: Dramatic literature, digitization and cultural...

1995. Print.

Twingle - Twangle: A TwynningTayle. Lagos: Longman,

Osundare, Niyi (2005). Two Plays: The Man Who Walked Away. Ibadan: University Press, Plc. Print.

Schipper, M. "Eurocentrism and Criticism: Reflections on the Study of Literature in Past and Present." World Literature Written in English. 24.1 (1984): 16-27.

Toyo, Eskor. Background to Globalisation. Ibadan: The Academic Staff Union of Universities, 2000. Print.

Trumbuli, Eric W. Introduction to Theatre: Online Course. Northern Virginia Community College, 2007. 